\section{Royal Commission for the Exhibition of 1851: Awards}

THE Commissioners for the Exhibition of 1851 have announced the award of Overseas Science Research Scholarships for 1948 to the following (the subject and place of research are given in brackets). On the recommendation of the University of Toronto: A. C. Hollis-Hallett (physics, University of Cambridge). On the recommendation of the University of Melbourne: N. N. Greenwood (physical chemistry, University of Cambridge). On the recommendation of the University of Sydney: Miss D. C. Davison (plant biochemistry, University of Cambridge); and P. B. Treacy (nuclear physics, University of Cambridge). On the recommendation of the University of New Zealand: C. F. Coleman (nuclear physics, University of Cambridge or Birmingham); D. S. Coombs (geology, University of Cambridge); and E. O. Hall (physies, University of Cambridge). On the recommendation of the University of Delhi : R. P. Bambah (mathematics, University of Cambridge or London). On the recommendation of the University of the Punjab : Miss M. Mehtab (cytology, University of Edinburgh).

\section{Institution of Electrical Engineers : Officers for 1948-49}

THE following officers and new members of Council of the Institution of Electrical Engineers have been elected to take office on September 30: President: Mr. T. Graeme N. Haldane; Vice-Presidents : Mr. A. J. Gill, Col. B. H. Leeson; Honorary Treasurer : Mr. E. Leete; New Members of Council: Mr. S. E. Goodall, Mr. H. W. Grimmitt, Mr. J. Hall, Dr. W. G. Radley, Dr. H. W. H. Warren, Mr. E. L. E. Wheatcroft, Mr. M. W. Humphrey Davies, Mr. A. V. Milton.

\section{Douglas Lea Memorial Lecture}

As a memorial to the late Dr. Douglas Edward Lea, the Hospital Physicists Association has decided to found a memorial lecture, to be given biennially during one of the meetings of the Association, by a worker of distinction in the field to which Dr. Lea had made many outstanding contributions, namely, the actions of radiation on living cells. The lectures will be open to the public, and the Association has set up a Trust Fund to cover the expenses of these lectures in perpetuity. Any income in excess of that required to meet the expenses of the lectures will be devoted to scientific research or publication. Friends of the late Dr. D. E. Lea who may wish to contribute to this Fund are asked to communicate in the first place with Mr. J. W. Boag, Medical Research Council, Hammersmith Hospital, London, W.12, who will notify them of the way in which contributions should be made.

\section{Announcements}

THE King in Council has approved of a charter granting full university status to the University College of Nottingham. Lord Trent, president of the College, will be the first chancellor; Mr. B. L. Hallward, head master of Clifton College, will be vice-chancellor.

THE Hungarian Academy of Science has established an Eötvös Medal in commemoration of the hundredth anniversary of the birth of the famous Hungarian physicist, Loránd Eötvös. The first Eötvös Medal has been awarded to Prof. J. Barnóthy and Dr. M.
Forró for their outstanding achievements in the realm of cosmic radiation.

The James Scott Prize for 1948 of the Royal Society of Edinburgh was presented to Prof. Herbert Dingle at the ordinary meeting of the Society held on July 5, 1948, at which, in terms of the Prize, Prof. Dingle delivered an address on "The Nature of Scientific Philosophy". The Neill Prize (1945-47) was presented in absentia to Dr. Robert Broom, for his contributions to our knowledge of the fossil vertebrates of the Karroo Beds of South Africa.

Dr. S. L. Hora, director of the Zoological Survey of India, has been appointed an honorary member of " 's Lands Plantentuin" by the staff of the scientific institutes of south-east Asia constituting this body. The letter from Dr. L. G. M. Bass Becking, director of the Botanic Gardens, Buitenzorg, giving this announcement, makes appreciative reference to $\mathrm{Dr}$. Hora's contributions to tropical zoology, to the spirit of co-operation and friendship he is always able to convey to colleagues abroad, and to the need for scientific men in south-east Asia to join forces in promoting reconstruction measures.

THE managers of the Royal Institution have made the first appointment to the Science Research Scholarships of the Institution offered to candidates from overseas universities. One of these scholarships is to be awarded each year on the advice and recom. mendation of the Science Scholarships Committee of the Royal Commission for the Exhibition of 1851 , and the award for 1948 has been made to Miss Philippa Marion Glasgow; Miss Glasgow is a physical chemist, and holds the degree of M.Sc. of the University of New Zealand.

THE following have been elected to Beit Fellowships for Scientific Research of the value of $£ 400$ per annum each, tenable at the Imperial College of Science and Technology: P. W. M. Jacobs, for research in physical chemistry under the direction of Prof. H. V. A. Briscoe; M. J. M. Bernal, for research in applied physical chemistry under the direction of Sir Alfred Egerton.

ThE Flatford Mill Field Centre of the Council for the Promotion of Field Studies, 10 Exhibition Road, London, S.W.7, will be formally opened by the chairman of the Carnegie United Kingdom Trust, Mr. E. Salter Davies, on July 23.

WE have received a copy of No. 1 of Vol. 2 of Quarterly Reviews, published by the Chemical Society (price to non-fellows, 8s. per number or 25s. per annum). It contains, in 91 pages, articles by $H . N$. Wilson and J. G. M. Bremner on "Disproportionation in Inorganic Compounds", by D. V. N. Hardy and N. J. L. Megson on "The Chemistry of Silicon Polymers", by L. J. Haynes on "Physiologically Active Unsaturated Lactones", and by A. D. Walsh on "Far Ultra-Violet Spectra, Ionisation Potentials, and their Significance in Chemistry". The publication is intended to be of interest to chemists generally and not only to workers in the fields reviewed. A limited number of additional subscriptions for Vol. 2 can be accepted.

Erratum. We regret that the illustration accompanying the communication entitled "Eye Move. ments During Monocular Fixation" by Drs. Mary P. Lord and W. D. Wright (Nature, July 3, p. 25) has been printed upside down. 